ORIGINAL ARTICLE

\title{
Genetic variability of the blue and red shrimp Aristeus antennatus in the Western Mediterranean Sea inferred by DNA microsatellite loci
}

\author{
Rita Cannas ${ }^{1 *}$, Flavio Sacco ${ }^{1 *}$, Maria Cristina Follesa ${ }^{1}$, Andrea Sabatini ${ }^{1}$, Marco Arculeo ${ }^{2}$, Sabrina Lo \\ Brutto $^{2}$, Teresa Maggio ${ }^{2}$, Anna Maria Deiana ${ }^{1} \&$ Angelo Cau ${ }^{1}$ \\ 1 Dipartimento di Scienze della vita e dell'ambiente, Università degli Studi di Cagliari, Cagliari, Italy \\ 2 Dipartimento di Biologia Animale 'G. Reverberi', Università di Palermo, Palermo, Italy
}

\section{Keywords}

Aristeus antennatus; DNA microsatellite; Mediterranean Sea; population genetics; sexbiased dispersal; shrimp.

\section{Correspondence}

Rita Cannas, Dipartimento di Scienze della vita e dell'ambiente, Università degli Studi di Cagliari, via T. Fiorelli 1, 09126 Cagliari, Italy. E-mail: rcannas@unica.it

\section{*These authors equally contributed to this} work.

Accepted: 4 November 2011

doi:10.1111/j.1439-0485.2011.00504.x

\begin{abstract}
Genetic variation at eight microsatellite loci was studied in nine populations of the blue and red shrimp Aristeus antennatus to investigate whether distinct stocks are present in the Western Mediterranean Sea. A high level of gene flow and no evidence of genetic partitioning were discovered. No significant variation was found $\left(\mathrm{F}_{\mathrm{ST}}=0.00673, \mathrm{P}\right.$-value $\left.=0.067\right)$ even when shrimps from exploited and those from deep-water unexploited grounds were compared. No evidence of reduction or expansion of population size in the recent past was found, as indicated by the bottleneck and interlocus g-tests. Our results are consistent with previous studies using mitochondrial gene methods and allozymes, indicating that, for this species, extensive pelagic larval dispersal and adult migration are probably responsible for the genetic homogeneity observed. In particular, due to a different bathymetric distribution of males and females, reported to be associated with different water masses and hence with possible differential dispersal capacity between sexes, the hypothesis of sex-biased dispersal was tested. Mean values of corrected assignment indices and mean relatedness values were higher for males, suggesting that females are the more widely dispersing sex. Molecular assessment of A. antennatus from the Western Mediterranean provides data of biological and evolutionary interest for the successful management of such a highly valuable fishery resource.
\end{abstract}

\section{Introduction}

The red and blue shrimp Aristeus antennatus (Risso, 1816) is the species with the widest depth distribution in the Mediterranean Sea: it is found over muddy bottoms of the slope, between $80 \mathrm{~m}$ (Nouar 2001) and $3300 \mathrm{~m}$ (Sardà et al. 2004) in the subtropical Atlantic and throughout the Mediterranean Sea (Crosnier \& Forest 1973).

Aristeus antennatus is an economically important resource. In the Western Mediterranean basin this species is usually fished with bottom-trawls at $500-800 \mathrm{~m}$ depth, but it is practically unexploited on the Eastern side (Papaconstantinou \& Kapiris 2001; Kapiris 2004). Catches of this shrimp are known to fluctuate considerably from year to year; recent studies have demonstrated the existence of a relationship between environmental factors (such as marine currents, water masses and climate variability) and abundance fluctuations of A. antennatus (Cartes et al. 2008, 2009; Company et al. 2008; Guijarro et al. 2008; Massuti et al. 2008; Maynou 2008a,b). In particular, higher landings have been recorded from 2 to 5 years after particularly cold winters and negative NAO (North Atlantic Oscillations) periods. The explanation for this is the increased dense shelf water formation with the cascading of superficial water masses that propagate along and across the continental slope. The transportation of 
particulate organic matter to the deep basin results in higher macrobenthos production, higher prey availability and, consequently, higher fecundity. The enhancement of recruitment could be also due to a higher larval survival with the increased food availability, and to the decrease of predation pressure caused by the turbidity anomalies generated in the deep layers after cascading events (Company et al. 2008).

In $A$. antennatus the dispersal of individuals is possible both in larval (by passive transport) and adult stages (mainly by active swimming). Actually, larvae of A. antennatus have been found only four times (Heldt 1954, 1955; Seridji 1971; Dos Santos 1998; Carbonell et al. 2010) and always in the upper layers, far from the adult fishing grounds, where they could have originated (Carbonell et al. 2010). It is probable that the newly hatched larvae perform a rapid and long vertical migration from the deeper spawning areas to the upper layers, where the later stages develop and are passively transported by the superficial currents (Carbonell et al. 2010). After this period, the individual becomes a young recruit and settles on deeper bottoms. Therefore, another major ontogenetic migration takes place when the post-larval stage moves to deeper waters. The recruitment has been observed on a wide depth range, with an increasing frequency of occurrence at greatest depths (D'Onghia et al. 2009). The occurrence of juveniles ( $<24 \mathrm{~mm} \mathrm{CL}$ ) and also very small individuals $(>6.2 \mathrm{~mm} \mathrm{CL}$ ) has been recorded from 450 to $650 \mathrm{~m}$ in Sardinian waters (Mura et al. 1997). Similarly, young-of-the-year have been caught on fishing grounds of the Ionian Sea (Papaconstantinou \& Kapiris 2001; D’Onghia et al. 2005). Small individuals ( $<10-15 \mathrm{~mm} \mathrm{CL})$ have also been observed at depths of $>1000 \mathrm{~m}$ in the Catalan, Balearic and Western Ionian Seas (Cartes \& Demestre 2003; Sardà et al. 2003a,b, 2004). Given that A. antennatus shows 'a bigger-shallower distribution trend' (Cartes \& Sardà 1993), with large-sized females found primarily on fishing grounds (mainly between 500 and $800 \mathrm{~m}$ depth) and the ratio unbalanced towards males below 800 m (Relini Orsi 1980; Mura \& Cau 1989; Sardà et al. 1994; Matarrese et al. 1995), the occurrence of a further upward displacement of adult females from deep recruitment grounds to fishing grounds could be hypothesized.

Moreover, seasonal changes in the sex-ratio pattern suggest an upward movement of males to shallower depths for mating during winter and early spring (Carbonell et al. 2008).

Finally, adult blue and red shrimps (both males and females) are known to perform diel (trophic) bathymetric migrations (Relini et al. 2000 and references therein).

As it is very difficult to track individuals for marine species, and even more challenging for the deep-water shrimp such as A. antennatus, the use of indirect methods for the measurement of connectivity among populations is important (Cowen et al. 2007). Among the most recent indirect methods to inferring connectivity, genetic approaches have been particularly successful (Hedgecock et al. 2007).

Information on the genetic structure and diversity of natural populations of $A$. antennatus throughout its natural range is very limited. Previous studies have shown the absence of population differentiation using either allozymes (Marchi et al. 1995; Pla et al. 1995; Sardà et al. 1998) or mtDNA markers (Maggio et al. 2009; Roldán et al. 2009; Sardà et al. 2010). Genetic homogeneity of A. antennatus populations has been explained by relatively recent separation in populations and/or ongoing gene flow, due to pelagic larvae dispersal and adult migrations.

The use of more variable and polymorphic molecular markers, such as microsatellites (also known as simple sequence repeats, SSR) could reveal the existence of genetically isolated populations, even if differentiation is very small, especially in fine-scale studies, where populations are closely related (Wright \& Bentzen 1994).

In this paper, genetic variation at eight microsatellite loci was studied in nine populations of the blue and red shrimp A. antennatus to quantify the genetic diversity, investigate population genetic structure, and assess whether distinct stocks occur in the Western Mediterranean Sea. Due to a different bathymetric distribution of the sexes and their possible differential dispersal capacity, we also tested the hypothesis of instantaneous sex-biased dispersal.

\section{Material and Methods}

Field collections

Individuals were collected from both commercial bottom trawling ( $\leq 800 \mathrm{~m}$ depth) and experimental deep-bottom trawling (from 800 to $1600 \mathrm{~m}$ ) in 2006-2008 from Algeria and eight Italian localities: Terrasini (Northwestern Sicily), Cala Gonone (Central-eastern Sardinia), Cagliari (Southern Sardinia), Vapore (Southern Sardinia), PescaProfonda-Sperimentale (henceforth PSP) South (Southeastern Sardinia), PSP North (Southeastern Sardinia), Sant'Antioco (Southwestern Sardinia) and San Remo (Ligurian Sea). PSP South and PSP North are the only localities where two different temporal replicates (2006 and 2007) were collected (Table 1, Fig. 1).

Tissue sampling, DNA extraction and microsatellite amplification

Muscle tissue was sampled from pereiopods or tails and preserved in $70-100 \%$ ethanol at $4{ }^{\circ} \mathrm{C}$. Total DNA was extracted following the 'Salting Out' protocol (Miller 
Table 1. Location, year of sampling, depth of capture, number and sex of individuals of each sample analyzed.

\begin{tabular}{llrr}
\hline Sample & $\begin{array}{l}\text { Year of } \\
\text { sampling }\end{array}$ & $\begin{array}{r}\text { Depth in m, } \\
\text { mean (max) }\end{array}$ & $\begin{array}{l}\text { No. of individuals } \\
\text { (males, females) }\end{array}$ \\
\hline Algeria & 2006 & $<800^{*}$ & $20(\mathrm{NA})$ \\
San Remo & 2007 & $<800^{*}$ & $29(\mathrm{NA})$ \\
Cala Gonone & 2007 & $<800^{*}$ & $20(0,20)$ \\
Terrasini & 2007 & $<800^{*}$ & $20(\mathrm{NA})$ \\
PSP North & 2006 & $1507(1621)$ & $12(4,8)$ \\
PSP North & 2007 & $1421(1422)$ & $12(1 / 11)$ \\
Sant'Antioco & 2007 & $<800^{*}$ & $26(6,20)$ \\
Cagliari & 2006 & $<800^{*}$ & $17(0,17)$ \\
PSP South & 2006 & $1117(1227)$ & $29(22,7)$ \\
PSP South & 2007 & $1110(1173)$ & $26(21,5)$ \\
Vapore & 2008 & $<800^{*}$ & $16(16,0)$ \\
Total & & & 227 \\
\hline
\end{tabular}

Individuals from commercial hauls (*) were presumably caught at $800 \mathrm{~m}$ depth or shallower. The sex of the individuals from Algeria, San Remo and Terrasini is unknown (NA), as only pereiopods, not complete specimens, were available for the genetic analyses. PSP (Pesca-Profonda-Sperimentale) indicates the experimental hauls.

et al. 1988) with minor modifications, and resuspended in $\mathrm{ddH}_{2} \mathrm{O}$. Individual genotypes were obtained using eight polymorphic microsatellite loci (Table 2) and following PCR conditions as in Cannas et al. (2008). PCR products together with a ROX 400 size standard underwent capillary electrophoresis at BMR-Genomics Laboratories in Padova, Italy (http://www.bmr-genomics.com). Allele sizes were then quantified using GENEMARKER ${ }^{\circledR}$ v.1.75 (Softgenetics, LCC State College, PA, USA).

\section{Genetic analyses}

Genetic variability for each sample was quantified with standard descriptive statistics. Number of alleles $(\mathrm{Na})$, observed $\left(\mathrm{H}_{\mathrm{o}}\right)$, unbiased expected heterozygosity $(\mathrm{UHe})$, and $\mathrm{F}_{\mathrm{IS}}$ inbreeding coefficient (Weir \& Cockerham 1984) were calculated using the software GENALEX v.6.4 (Peakall \& Smouse 2006) and GENEPOP v.4.0 (Rousset 2008). Allelic richness (Ra), calculated in FSTAT 2.9.3 using the rarefaction method (Goudet et al. 2002), was corrected to the smallest population (Vapore) to increase the power of detecting differences in $\mathrm{Ra}$ (Leberg 2002), and results averaged across loci. Polymorphism information content (PIC) values for all loci over all samples were calculated using the EXCEL Microsatellite Toolkit v. 3.1.1 (Park 2001). PIC values, which reflect the value of a marker for detecting polymorphism within a population, were calculated according to the formula:

$$
\mathrm{PIC}_{\mathrm{i}}=1-\sum_{\mathrm{j}=1}^{\mathrm{n}} \mathrm{P}_{\mathrm{ij}}^{2}
$$

where $\mathrm{P}_{\mathrm{ij}}$ is the frequency of the jth allele for the ith marker summed over $\mathrm{n}$ alleles (Anderson et al. 1993).

GENEPOP was also used to test genotypic linkage disequilibrium and deviations from Hardy-Weinberg equilibrium (HWE) measured as heterozygosity deficiency, for each locus and globally (Markov chain 1000 dememorization steps, 100 batches and 1000 iterations per batch).

Significance levels were adjusted with sequential Bonferroni corrections for multiple tests using the program SGOF (Carvajal-Rodriguez et al. 2009).

Differences among locations and temporal samples for the mean $\mathrm{H}_{\mathrm{o}}$ and UHe were assessed using the ANOVA $\mathrm{F}$ statistic; $\mathrm{Na}$ and $\mathrm{Ra}$ differences were tested using the Mann-Whitney $U$ test. To determine whether the departure from panmixia was due to the presence of null alleles, the FREENA package (Chapuis \& Estoup 2007) was used, and a maximum-likelihood estimate was calculated for the frequency of null alleles according to Dempster et al. (1977). The same software was used to compute a genotype data set corrected for null alleles

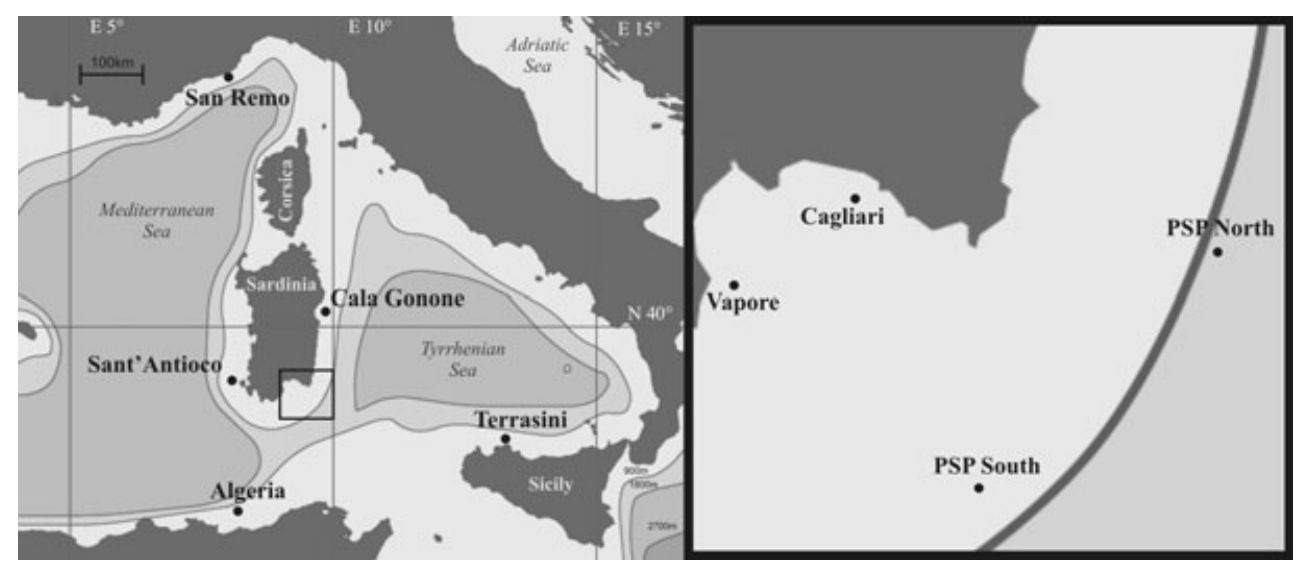

Fig. 1. Map of the sampling sites. The right square represents an enlargement of the Gulf of Cagliari. 
Table 2. Parameters of genetic diversity in Aristeus antennatus analyzed from eight microsatellite loci.

\begin{tabular}{|c|c|c|c|c|c|c|c|c|c|c|}
\hline Sample & & ant93 & ant94 & ant99 & ant66 & ant37 & ant194 & ant34 & ant82 & All loci \\
\hline \multirow[t]{6}{*}{ Algeria } & $\mathrm{N}$ & 20 & 20 & 20 & 20 & 20 & 20 & 20 & 20 & 20 \\
\hline & $\mathrm{Na}$ & 5 & 9 & 6 & 8 & 11 & 12 & 11 & 6 & 8.5 \\
\hline & $\mathrm{Ra}$ & 4.7 & 8.56 & 5.51 & 7.01 & 9.46 & 9.81 & 10.1 & 5.89 & 8.08 \\
\hline & $\mathrm{Ho}$ & 0.35 & 0.6 & 0.55 & 0.7 & 0.9 & 0.95 & 0.7 & 0.5 & 0.66 \\
\hline & UHe & 0.72 & 0.87 & 0.68 & 0.78 & 0.82 & 0.84 & 0.89 & 0.8 & 0.8 \\
\hline & $\mathrm{Nu}$ & 0.21 & 0.14 & 0.03 & 0.05 & 0.00 & 0.00 & 0.09 & 0.16 & \\
\hline \multirow[t]{6}{*}{ San Remo } & $\mathrm{N}$ & 29 & 29 & 29 & 29 & 29 & 29 & 29 & 29 & 29 \\
\hline & $\mathrm{Na}$ & 5 & 11 & 6 & 10 & 7 & 9 & 9 & 9 & 8.25 \\
\hline & $\mathrm{Ra}$ & 4.35 & 9.24 & 5.34 & 7.57 & 6.21 & 7.66 & 8.51 & 7.87 & 7.09 \\
\hline & Ho & 0.31 & 0.66 & 0.52 & 0.72 & 0.79 & 0.76 & 0.66 & 0.55 & 0.62 \\
\hline & UHe & 0.72 & 0.84 & 0.72 & 0.81 & 0.78 & 0.77 & 0.88 & 0.85 & 0.8 \\
\hline & Fis & $0.57 * * *$ & 0.22 & 0.29 & 0.11 & -0.02 & 0.01 & $0.26 * * *$ & $0.36 *$ & \\
\hline \multirow[t]{7}{*}{ Cala Gonone } & $\mathrm{N}$ & 19 & 20 & 20 & 20 & 20 & 20 & 20 & 20 & 20 \\
\hline & $\mathrm{Na}$ & 5 & 10 & 6 & 5 & 7 & 12 & 9 & 6 & 7.5 \\
\hline & $\mathrm{Ra}$ & 4.73 & 8.93 & 5.67 & 4.97 & 6.59 & 10.08 & 8.38 & 5.38 & 6.84 \\
\hline & $\mathrm{Ho}$ & 0.21 & 0.75 & 0.6 & 0.6 & 0.85 & 0.9 & 0.55 & 0.5 & 0.62 \\
\hline & UHe & 0.72 & 0.87 & 0.75 & 0.76 & 0.8 & 0.79 & 0.88 & 0.75 & 0.79 \\
\hline & Fis & $0.71 * * *$ & 0.14 & 0.21 & 0.21 & -0.07 & -0.14 & $0.38 * * *$ & 0.34 & \\
\hline & $\mathrm{Nu}$ & 0.29 & 0.04 & 0.08 & 0.10 & 0.00 & 0.00 & 0.17 & 0.13 & \\
\hline \multirow[t]{7}{*}{ Terrasini } & $\mathrm{N}$ & 20 & 20 & 20 & 20 & 20 & 20 & 20 & 20 & 20 \\
\hline & $\mathrm{Na}$ & 7 & 13 & 6 & 7 & 8 & 15 & 10 & 10 & 11 \\
\hline & $\mathrm{Ra}$ & 6.23 & 11.29 & 5.65 & 6.23 & 7.51 & 12.54 & 9.2 & 8.61 & 8.41 \\
\hline & $\mathrm{Ho}$ & 0.35 & 0.8 & 0.7 & 0.6 & 0.8 & 0.9 & 0.5 & 0.75 & 0.68 \\
\hline & UHe & 0.74 & 0.87 & 0.72 & 0.72 & 0.83 & 0.88 & 0.87 & 0.83 & 0.81 \\
\hline & Fis & $0.54 *$ & 0.08 & 0.03 & 0.18 & 0.04 & -0.02 & 0.43 & 0.10 & \\
\hline & $\mathrm{Nu}$ & 0.22 & 0.03 & 0.01 & 0.09 & 0.00 & 0.00 & 0.18 & 0.07 & \\
\hline \multirow{5}{*}{ PSP South } & $\mathrm{Ra}$ & 5.73 & 9.5 & 5.84 & 5.76 & 7.68 & 7.33 & 8.11 & 7.95 & 7.24 \\
\hline & Ho & 0.6 & 0.72 & 0.64 & 0.58 & 0.76 & 0.62 & 0.61 & 0.71 & 0.66 \\
\hline & UHe & 0.77 & 0.87 & 0.69 & 0.7 & 0.79 & 0.7 & 0.84 & 0.84 & 0.78 \\
\hline & Fis & $0.22 * \star *$ & 0.18 & 0.07 & 0.18 & 0.04 & 0.11 & $0.28 *$ & $0.15^{\star}$ & \\
\hline & $\mathrm{Nu}$ & 0.10 & 0.07 & 0.05 & 0.06 & 0.00 & 0.06 & 0.12 & 0.08 & \\
\hline \multirow[t]{7}{*}{ PSP North } & $\mathrm{N}$ & 24 & 23 & 24 & 24 & 24 & 24 & 24 & 24 & 24 \\
\hline & $\mathrm{Na}$ & 6 & 10 & 7 & 7 & 10 & 9 & 9 & 10 & 18 \\
\hline & $\mathrm{Ra}$ & 5.16 & 9.09 & 5.87 & 5.93 & 8.26 & 7.45 & 8.26 & 9.72 & 7.47 \\
\hline & Ho & 0.46 & 0.7 & 0.88 & 0.54 & 0.83 & 0.58 & 0.75 & 0.83 & 0.7 \\
\hline & UHe & 0.76 & 0.88 & 0.69 & 0.74 & 0.86 & 0.78 & 0.86 & 0.9 & 0.81 \\
\hline & Fis & $0.40 * * *$ & 0.21 & -0.27 & 0.28 & 0.03 & 0.26 & 0.13 & 0.08 & \\
\hline & $\mathrm{Nu}$ & 0.17 & 0.10 & 0.00 & 0.10 & 0.00 & 0.11 & 0.07 & 0.04 & \\
\hline \multirow[t]{7}{*}{ Sant'Antioco } & $\mathrm{N}$ & 26 & 26 & 26 & 26 & 26 & 26 & 26 & 26 & 26 \\
\hline & $\mathrm{Na}$ & 5 & 13 & 5 & 8 & 8 & 11 & 11 & 12 & 15 \\
\hline & $\mathrm{Ra}$ & 4.52 & 10.07 & 4.78 & 6.28 & 7.13 & 9.05 & 9.22 & 9.22 & 7.53 \\
\hline & $\mathrm{Ho}$ & 0.27 & 0.69 & 0.54 & 0.65 & 0.69 & 0.81 & 0.62 & 0.62 & 0.61 \\
\hline & UHe & 0.74 & 0.85 & 0.72 & 0.7 & 0.82 & 0.84 & 0.85 & 0.84 & 0.8 \\
\hline & Fis & $0.64^{* * *}$ & 0.19 & 0.26 & 0.07 & 0.15 & 0.03 & 0.28 & $0.27 *$ & \\
\hline & $\mathrm{Nu}$ & 0.27 & 0.06 & 0.11 & 0.03 & 0.05 & 0.00 & 0.11 & 0.11 & \\
\hline \multirow[t]{7}{*}{ Cagliari } & $\mathrm{N}$ & 17 & 17 & 17 & 17 & 17 & 17 & 17 & 16 & 17 \\
\hline & $\mathrm{Na}$ & 6 & 13 & 5 & 6 & 7 & 9 & 10 & 10 & 12 \\
\hline & $\mathrm{Ra}$ & 5.94 & 11.9 & 4.65 & 5.47 & 6.65 & 7.91 & 9.44 & 9.71 & 7.71 \\
\hline & $\mathrm{Ho}$ & 0.24 & 0.71 & 0.47 & 0.65 & 0.82 & 0.65 & 0.94 & 0.69 & 0.64 \\
\hline & UHe & 0.75 & 0.9 & 0.58 & 0.73 & 0.83 & 0.66 & 0.88 & 0.9 & 0.78 \\
\hline & Fis & $0.69 * * *$ & 0.22 & 0.19 & 0.12 & 0.01 & 0.01 & -0.07 & 0.24 & \\
\hline & $\mathrm{Nu}$ & 0.29 & 0.09 & 0.05 & 0.02 & 0.00 & 0.00 & 0.00 & 0.10 & \\
\hline
\end{tabular}


Table 2. (Continued)

\begin{tabular}{|c|c|c|c|c|c|c|c|c|c|c|}
\hline Sample & & ant93 & ant94 & ant99 & ant66 & ant37 & ant194 & ant34 & ant82 & All loci \\
\hline \multirow[t]{6}{*}{ Vapore } & $\mathrm{N}$ & 14 & 16 & 16 & 16 & 16 & 16 & 16 & 16 & 16 \\
\hline & $\mathrm{Na}$ & 5 & 8 & 6 & 5 & 7 & 9 & 11 & 8 & 7.38 \\
\hline & $\mathrm{Ra}$ & 5 & 7.87 & 5.74 & 4.74 & 6.85 & 8.59 & 10.59 & 7.74 & 7.14 \\
\hline & Ho & 0.64 & 0.56 & 0.69 & 0.56 & 0.69 & 0.69 & 0.88 & 0.88 & 0.7 \\
\hline & UHe & 0.81 & 0.88 & 0.7 & 0.61 & 0.82 & 0.76 & 0.9 & 0.84 & 0.79 \\
\hline & $\mathrm{Nu}$ & 0.08 & 0.15 & 0.00 & 0.00 & 0.06 & 0.00 & 0.01 & 0.00 & \\
\hline \multirow[t]{6}{*}{ All populations } & Mean N & 24.67 & 24.89 & 25 & 25.22 & 25.22 & 25.22 & 25.11 & 25.11 & 25.05 \\
\hline & $\mathrm{Na}$ & 10 & 21 & 9 & 11 & 12 & 18 & 15 & 12 & 13.5 \\
\hline & $\mathrm{Ra}$ & 5.28 & 10.06 & 5.53 & 6.05 & 7.61 & 8.64 & 8.98 & 8.44 & 7.57 \\
\hline & $\mathrm{PIC}$ & 0.71 & 0.86 & 0.65 & 0.69 & 0.79 & 0.75 & 0.86 & 0.83 & 0.77 \\
\hline & Mean Ho & 0.38 & 0.69 & 0.62 & 0.62 & 0.79 & 0.76 & 0.69 & 0.67 & 0.65 \\
\hline & Mean UHe & 0.75 & 0.87 & 0.69 & 0.73 & 0.82 & 0.78 & 0.87 & 0.84 & 0.8 \\
\hline
\end{tabular}

Number of individuals $(\mathrm{N})$, total alleles $(\mathrm{Na})$, allelic richness $(\mathrm{Ra})$, observed heterozygosity $\left(\mathrm{H}_{\mathrm{O}}\right)$, unbiased expected heterozygosity (UHe) for each sample, each locus and average values for all loci/all samples are reported.

Significant departures from Hardy-Weinberg (HWE) after sequential Bonferroni correction are indicated next to the FIS values: ${ }^{* \star} \mathrm{P}<0.001$,

$* \mathrm{P}<0.05$. Frequencies of null alleles $(\mathrm{Nu})$ estimated by FreeNa are shown for each locus. For all loci the polymorphism information content (PIC) is indicated.

following the INA (including null alleles) method described in Chapuis \& Estoup (2007). This new dataset was used to recalculate the mean expected heterozygosity (He, Nei 1987) as a measure of genetic variability within samples because the presence of null alleles only has a limited effect on this statistic (Chapuis \& Estoup 2007).

Microsatellite data were used to calculate the EwensWatterson neutrality test for all loci using the algorithm given in Manly (1985) and implemented in the software POPGENE v 1.32 (Yeh et al. 1998). The observed sum of the squared allele frequencies (observed F) was compared with the 95\% confidence intervals (calculated using 1000 simulated samples) for the expected sum of the squared allele frequencies (expected F). This test is useful for detecting recent or current deviations from mutation-drift equilibrium due to selection or demographic changes.

Possible reductions or expansions in size of sampled populations were tested for each sample using different approaches.

To test for the signature of a very recent reduction in population size, the distribution of the heterozygosity expected under the two-phased model of mutation (TPM) with a $7 \%$ of multi-step changes (Luikart et al. 1998) was measured for each population and for each locus with BOTTLENECK v.1.2.02 (Piry et al. 1999); heterozygosity excess was detected with the one-tailed Wilcoxon sign-rank test (Luikart et al. 1998), which is the best method for studies using fewer than 20 loci (Piry et al. 1999). The same software was used to look at a graphical descriptor of the shape of the allele frequency distribution. A population that has not suffered a recent bottleneck event will yield an L-shape distribution (such as expected in a stable population in mutation-gene drift equilibrium). Signatures of expansion were examined using two approaches: the imbalance index $\beta$ (Kimmel et al. 1998; King et al. 2000) and the interlocus g-test (Reich \& Goldstein 1998; Reich et al. 1999).

The imbalance index (Kimmel et al. 1998; King et al. 2000) compares the distribution of length differences among microsatellite alleles; in particular, the $\ln \beta$ metric was chosen because of its ability and power to detect historic signals of population expansion (King et al. 2000). First, the variance estimator $\left(\theta_{\mathrm{V}}\right)$ and the homozygosity estimator $\left(\theta_{\mathrm{H}}\right)$ were calculated from equations 1 and 3 of Kimmel et al. (1998). Then the imbalance index $(\ln \beta)$ was calculated as the difference in the natural logarithm of these two estimators, averaged over all microsatellite loci.

The test statistic g, calculated by the Kgtests EXCEL macro (Bilgin 2007), is interpreted as indication of an expansion when it has an unusually low value (Reich et al. 1999); in our case, g values lower than 0.14-0.16 will indicate a population expansion. Significance levels for the interlocus g-test are available in Table 1 in Reich et al. (1999).

An analysis of molecular variance (AMOVA) (Excoffier et al. 1992) was used to estimate partitioning of genetic variance within and among samples and among groups, where samples were pooled on a geographical basis. To test the hypothesis of panmixia, pairwise $\mathrm{F}_{\mathrm{ST}}$ values were computed on the original dataset using ARLEQUIN v.3.1 (Excoffier et al. 2005); the significance of pairwise $\mathrm{F}_{\mathrm{ST}}$ values were tested using a nonparametric Monte Carlo approach (100,172 permutations). Significance levels for pairwise $\mathrm{F}_{\mathrm{ST}}$ were adjusted with sequential Bonferroni 
corrections. $\mathrm{F}_{\mathrm{ST}}$ values (Weir 1996) were also computed following the so-called ENA method described in Chapuis \& Estoup (2007) to provide accurate estimation of $\mathrm{F}_{\mathrm{ST}}$ in the presence of null alleles.

\section{Sex-biased dispersal}

To test for sex-biased instantaneous dispersal the following software was used: FSTAT version 2.9.3 (that allows analyses of genotypes where ' 00 ' alleles are scored, but not populations exclusively composed of individuals of the same sex, as in the case of Cala Gonone); GENECLASS v.2.0 (Piry et al. 2004) and GENALEX v.6.2. (where individuals bearing null alleles are excluded but unisex populations are allowed). $\mathrm{F}_{\mathrm{IS}}, \mathrm{F}_{\mathrm{ST}}$, mAIc and vAIc were calculated with FSTAT version 2.9.3; statistical significance for these indices was determined by 10,000 randomizations.

Assignment values for each individual in each sample were transformed to corrected assignment indices (AIc; Favre et al. 1997; Goudet et al. 2002). The mean population AIc is zero, and the lower AIc value an individual has, the higher is the probability that the individual is a disperser from another population (Bekkevold et al. 2004).

As the accuracy and higher discriminant power of the Bayesian assignment method of individual-based assignment to measure dispersal has been assessed recently (Berry et al. 2004; Lawson Handley \& Perrin 2007), mAIc assignment indices were also computed with GENECLASS v.2.0 (Piry et al. 2004), using the Bayesian assignment approach developed by Rannala \& Mountain (1997). The MannWhitney $U$-test was applied to verify whether AIc values for males and females were significantly differentiated.

The mean relatedness index $(r)$ between individuals of each sex was calculated using the method of Queller \& Goodnight (1989) implemented in GENALEX v.6.2.

It is worth noting that the biparental markers utilized here (i.e. microsatellites) convey information on shortterm dispersal (i.e. after dispersal, before mating). Therefore, the sex-biased migration signal will disappear after one generation of random mating due to Mendelian segregation if the dispersal is no longer sex-biased (Goudet et al. 2002; Prugnolle \& de Meeus 2002). However, a significant proportion of the migrants may disperse but not reproduce in the new population. This would maintain allele frequency differences between the populations and allow the detection of immigrants within every generation.

\section{Results}

\section{Genetic diversity}

A total of 227 individuals were successfully genotyped; none of the individuals shared the same diploid genotype
(Table 2). All the eight microsatellite loci were polymorphic across all populations and characterized by high polymorphism information content (PIC) values (mean 0.77 ; range $0.65-0.86$ ). No linkage disequilibrium between pairs of loci was detected and therefore they were considered statistically independent and were treated as independent markers.

Estimators of genetic diversity varied through loci and populations, with variable levels of polymorphism (Table 2). Total numbers of alleles per locus $(\mathrm{Na})$ ranged from a minimum of nine (locus ant99) to a maximum of 21 (locus ant94), with a mean of 13.5 alleles per locus. The observed heterozygosity ( $\mathrm{Ho}$ ) for the eight loci ranged from 0.38 to 0.79 (mean 0.65 ), the unbiased expected heterozygosity (UHe) from 0.69 to 0.87 (mean 0.8 ), and the allelic richness from 5.28 to 10.06 (mean 7.57).

The ANOVA $\mathrm{F}$ and Mann-Whitney $U$-tests used for comparing, respectively, observed and expected heterozygosity, and mean allelic number and allelic richness, revealed no significant differences among sampling sites and temporal samples (for all tests: $\mathrm{P}>0.05$ ), thus in all the following analyses the samples collected in different years from the same locality were pooled together.

Some samples deviated significantly from Hardy-Weinberg equilibrium at three microsatellite loci (Table 2). After sequential Bonferroni corrections, significant heterozygote deficit was found in 14 of 72 comparisons (eight loci $\times$ nine populations). If the nine populations were considered as a whole, six of eight loci in multi-sample tests deviated from the HWE.

The program FREENA indicated that the departures from HWE were probably due to the presence of null alleles; all loci exhibited null allele frequencies $>0$, but only locus ant 93 was in excess of $20 \%$ and other three loci they were in excess of $5 \%$ (Table 2).

Considering the $\mathrm{F}_{\mathrm{IS}}$ estimates for each locus, significant positive values, indicative of heterozygote deficiencies, were observed at locus ant93 in all samples, except for Vapore, and at other two loci (ant34 and ant82) but only in a few samples (Table 2).

The overall Ewens-Watterson test for neutrality (pooled across samples) showed that none of the values for the eight loci were outliers for the lower and upper boundaries of the $95 \%$ confidence region. Similar results were obtained for the Ewens-Watterson test within each sample (data not shown).

\section{Growth and reduction of population size}

In this study, none of the populations showed either excess of heterozygosity (Table 3) or exhibited shifted frequency distributions of alleles (data not shown). Bottleneck tests 
Table 3. Results of bottleneck and interlocus g-tests. The column TPM reports the Wilcoxon sign-rank test P-value for heterozygosity excess under the TPM model (two-phased model of mutation).

\begin{tabular}{lll}
\hline Sample & TPM & g-test (value) \\
\hline Algeria & 0.81 & 0.99 \\
San Remo & 0.58 & 1.57 \\
Cala Gonone & 0.10 & 4.47 \\
Terrasini & 0.99 & 1.47 \\
PSP South & 0.98 & 0.94 \\
PSP North & 0.42 & 3.61 \\
Sant'Antioco & 0.96 & 1.10 \\
Cagliari & 0.68 & 4.66 \\
Vapore & 0.47 & 5.38 \\
All & 0.01 & 0.80 \\
\hline
\end{tabular}

indicated that the analyzed samples had not experienced a recent reduction in size.

From the microsatellite dataset, the variance estimator $\left(\theta_{\mathrm{V}}\right)$ and the homozygosity estimator $\left(\theta_{\mathrm{H}}\right)$ for each sample were calculated, resulting in imbalance indices $\ln \beta$ that were always $>1$ (range 5.6-7.04, mean 6.67). The imbalance index is $<1$ for expanding populations whose pre-expansion history is stable, but it is $>1$ in populations with a reduction in size that precedes a detectable growth phase (Kimmel et al. 1998). Our results indicate that the populations may have experienced, in the past, a growth phase following an earlier reduction. Nevertheless, the more conservative interlocus g-test, interpreted as indication of population expansion when it assumes very low values, did not show any evidence of expansion either overall or in each sample studied. The g-statistic was 0.8 for the global sample, and ranged from 0.94 in PSP South to 5.38 in Vapore (Table 3). These values did not reach a $\mathrm{g}=0.14-0.16$, which had been significant for the number of loci and samples analyzed.

\section{Genetic structure analyses}

AMOVA (Table 4) revealed that the proportion of global genetic variance was mostly attributed to differences among individuals $(99.33 \%)$, whereas the proportion of genetic variation among samples was not significant
$\left(\mathrm{F}_{\mathrm{ST}}=0.00673, \mathrm{P}\right.$-value $\left.=0.06723 \pm 0.00076\right)$. Similarly, when samples were pooled in different groups according to the geographical origin of individuals (Tyrrhenian, Algerian and Ligurian basins), any significant genetic differentiation was found among the different areas ( $\mathrm{P}>$ 0.05, data not shown).

After sequential Bonferroni corrections none of the $\mathrm{F}_{\mathrm{ST}}$ pairwise values were significant, using both the original and the INA corrected database for the presence of null alleles.

\section{Sex-biased dispersal}

Sex-biased dispersal was tested for all specimens for which the sex was directly determined (six of nine populations; 158 specimens: 88 females and 70 males, see Table 1). Individuals from the remaining three populations (Algeria, San Remo, Terrasini) were excluded from these analyses as only pereiopods were sent to the laboratory, making sex determination impossible.

For all the following analyses, males and females were pooled into two different groups, group $\mathrm{M}$ and group F, respectively.

The fixation indices $F_{I S}, F_{S T}$, the mean relatedness index $\mathrm{r}$, the mean and variance of corrected assignment indices (mAIc and vAIc) values for males and females are shown in Table 5.

Four measurements (except $\mathrm{F}_{\mathrm{ST}}$ ) point towards a female-biased dispersal: $F_{I S}$ and vAIc values were higher in $\mathrm{F}$ than in $\mathrm{M}$, and $\mathrm{r}$ and mAIc values were negative in $\mathrm{F}$ but positive in M. Nevertheless, only the Mann-Whitney $U$-test turned out to be significant: the distribution of AIc values for males and females (Fig. 2a,b) was statistically different $(\mathrm{Z}=2.54$, one-tailed $\mathrm{P}=0.0056)$. The relative power of these indices to detect a sex bias in the dispersal depends on the magnitude of the bias, dispersal rates, sampling scheme and markers examined (Goudet et al. 2002). When the gene flow is quite high, individual-based assignment tests are expected to be more powerful than summary statistics ( $\mathrm{F}_{\mathrm{IS}}, \mathrm{F}_{\mathrm{ST}}$, which represents a population 'average'); in fact, they provide a qualitative and quantitative idea of the scale of dispersal because they do not average over the sample.

Table 4. Analysis of molecular variance AMOVA.

\begin{tabular}{|c|c|c|c|c|c|}
\hline Source of variation & $d f$ & $\begin{array}{l}\text { Sum of } \\
\text { squares }\end{array}$ & $\begin{array}{l}\text { Variance } \\
\text { components }\end{array}$ & $\begin{array}{l}\text { Percentage of } \\
\text { variation }\end{array}$ & Fixation indices \\
\hline Among populations & 8 & 33.342 & 0.02118 & 0.67 & $\mathrm{~F}_{\mathrm{ST}}=0.00673^{*}$ \\
\hline Within populations & 445 & 1391.065 & 3.12599 & 99.33 & \\
\hline Total & 453 & 1424.407 & 3.14717 & & \\
\hline
\end{tabular}

*P-value $=0.06723 \pm 0.00076(1,00,172$ permutations $)$. 
Table 5. Deviation from Hardy-Weinberg expectation $\left(F_{I S}\right)$, fixation index $F_{S T}$, relatedness ( $r$ ), variance assignment (vAlc), mean assignment (mAlc) values estimated separately for male (M) and female (F) A. antennatus specimens are shown.

\begin{tabular}{llrrrrr}
\hline & \multicolumn{1}{l}{$\mathrm{F}_{\mathrm{IS}}$} & \multicolumn{1}{l}{$\mathrm{F}_{\mathrm{ST}}$} & \multicolumn{1}{c}{ vAlc } & mAlc $^{\mathrm{a}}$ & mAlc $^{\mathrm{b}}$ \\
\hline Females & 0.19 & 0.0052 & -0.020 & 8.87 & -0.299 & -0.251 \\
Males & 0.15 & -0.0013 & 0.003 & 7.28 & 0.304 & 0.330 \\
\hline
\end{tabular}

${ }^{a}$ Calculated with FSTAT.

${ }^{\mathrm{b}}$ Calculated with GENECLASS.

\section{Discussion}

\section{Genetic diversity}

All the eight loci showed high polymorphism; the PIC value per locus ranged from 0.65 to 0.86 , which was much more than the standard value of 0.5 (Botstein et al. 1980), so these values were suitable for population analyses.
The availability of informative markers for genetic analyses in Penaeoidea species is a problematic issue, as the isolation of microsatellite loci is quite difficult, owing to the large and complex repeat arrays found and the insufficient flanking sequences obtained, which made them unavailable for primer design (Ball et al. 1998; Tassanakajon et al. 1998; Xu et al. 1999).

The genetic diversity of Aristeus antennatus populations was high both for the numbers of alleles (mean 13.5 alleles per locus) and for the heterozygosities: the mean observed heterozygosity over all loci was 0.65 , less than the 0.80 mean value for the unbiased expected heterozygosity. These diversity parameters were in the range of those reported for other Penaeoidea species analyzed with microsatellites (Brooker et al. 2000; Supungul et al. 2000; $\mathrm{Xu}$ et al. 2001; Maggioni et al. 2003; Ward et al. 2006; Borrell et al. 2007; Li et al. 2007; Robainas-Barcia et al. 2008; You et al. 2008; Meng et al. 2009). The average heterozygosity levels of microsatellite data for A. antennatus were about 10 times higher than those obtained in
Fig. 2. Sex-specific Alcs (assignment indices corrected) for Aristeus antennatus. The calculated single values are shown in (a) and the mean values for the two sexes in (b). a

Male vs female assignment bias

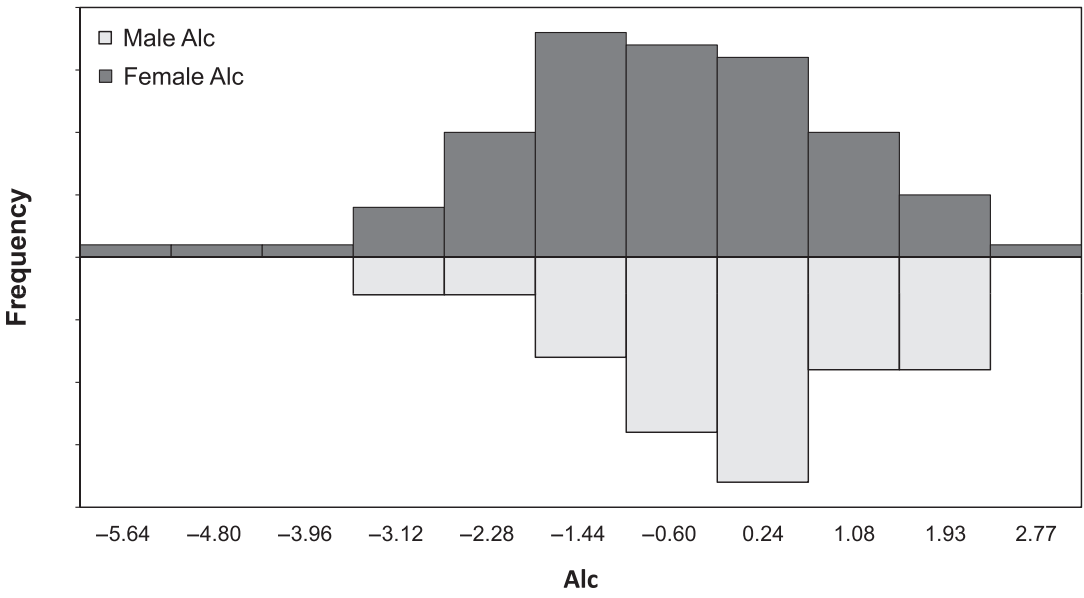

b Male vs female mean assignment bias

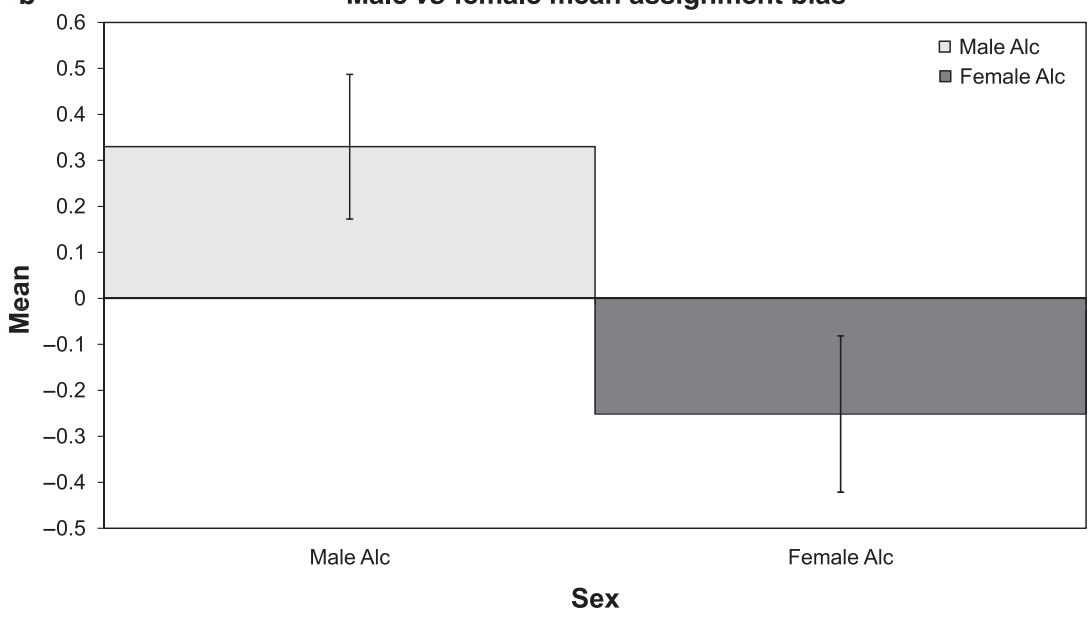


previous studies with allozyme data; in fact, the expected heterozygosity ranged from 0.077 to 0.095 in A. antennatus populations from Sardinia and Sicily (Marchi et al. 1995) and even lower values were found in red and blue shrimps from several localities both in the Atlantic and Western Mediterranean, where He ranged from 0.043 to 0.066 (Sardà et al. 1998).

The high-level polymorphism confirmed microsatellites as suitable markers to analyze the genetic variation of A. antennatus populations.

\section{HWE equilibrium}

In the present study, significant deviations from HardyWeinberg equilibrium were found (Table 2); heterozygote deficiencies were always responsible for these deviations. Similar deficits have been widely observed and regarded as quite common in shrimp species (Li et al. 2007; Robainas-Barcia et al. 2008; You et al. 2008; Meng et al. 2009).

The causes of deviation include scoring errors, inbreeding, selection, population admixture, and null alleles.

Stutter-related scoring errors were absent in our analysis because the alleles of the eight microsatellites could be scored unambiguously.

Inbreeding might not explain heterozygote deficiency in our species, as our samples came from wild populations that are supposed to be outbred. Furthermore, when the inbreeding coefficient $\mathrm{F}_{\mathrm{IS}}$ was calculated, it was significantly positive only in a few cases, mostly in locus ant93.

Microsatellites are supposed to be neutral markers, therefore selection cannot be invoked. The Ewens-Watterson neutrality test confirmed that all loci were selectively neutral.

The Wahlund effect, that is, heterozygote deficiency as caused by subpopulation structure, is not plausible in our case because genetically different sources of individuals were not confirmed by the analyses and therefore arbitrary admixture of individuals cannot be invoked to explain heterozygote deficiency. The presence of null alleles remains the most plausible reason for the departures from HWE in all populations. In fact, the analysis of HWE assuming the presence of null alleles (genotypes corrected with the INA method) showed that all localities were in equilibrium.

Throughout HWE analyses, one locus (ant93) was mainly responsible for almost all the deviations, suggesting that it could be excluded in future studies.

\section{Spatial and temporal variation}

Our results showed lack of significant differences in mean allelic numbers, heterozygosities (observed and expected), and allelic richness among sampling sites. It is important to highlight the absence of differences between commercial stocks (samples from exploited grounds) and deeper stocks regarded by several authors as virgin stocks (e.g. PSP samples, not yet exploited by trawl fishing).

Similarly, no differences were found among temporal samples. This seems to indicate a high genetic diversity, substantially stable over the 3 years of analysis. Actually, it is a very short period to draw final conclusions on the genetic stability of A. antennatus populations; it will be important to extend genetic monitoring over longer periods. In fact, the results of previous studies on prawns (Robainas-Barcia et al. 2005, 2008) highlighted the importance of analyzing a large number of spatial and temporal samples. In the pink prawn Farfantepenaeus notialis significant changes over years have been detected with very unstable and highly pronounced genetic structure (Robainas-Barcia et al. 2005, 2008). Farfantepenaeus notialis population structure has been altered by environmental factors (mainly hurricanes, which involved large changes in marine current patterns and hence in larval dispersal and recruitment), resulting in the alternation between the existence of genetically different local populations and the presence of a single, panmictic population.

In organisms like marine shrimps, characterized by high fecundity and significantly early mortality, another possible cause of changes in allele frequencies is the high variance in reproductive success (reproductive sweepstakes). This, combined with rapidly increasing fishing pressure, may contribute to reducing effective population sizes and thus lead to measurable fluctuations in gene frequencies over either geographical or temporal scales (Ball \& Chapman 2003). In the white shrimp Litopenaeus setiferus, populations sampled within 2 years showed significant temporal changes in allele frequencies (Ball \& Chapman 2003). The authors suggested that white shrimp populations could have experienced great demographic fluctuations caused by different factors, probably affecting the temporal stability of allele frequencies.

In $A$. antennatus, marked inter-annual fluctuations are known and described as strictly linked to environmental factors promoting variations in mobility patterns (see Introduction for details on this topic). Therefore, in this species it will be important to extend the genetic analyses over several years to determine whether the yearto-year differences in abundances (not only of the census population sizes but presumably also of the effective population sizes) could alter the genetic structure of populations.

\section{Reduction and growth of populations}

Bottleneck and interlocus g-tests failed to detect patterns consistent with variations in size in the contemporary 
gene pools. Both these analyses indicated that today Aristeus antennatus populations are stable.

However, the imbalance index $\ln \beta$, always $>1$, indicated that before the population reached its present size, there had probably been a previous reduction in size. This is consistent with mtDNA data of previous studies, where the mismatch analyses indicated a sudden population expansion after a bottleneck event which could have occurred about 2000 years ago (Maggio et al. 2009; Roldán et al. 2009).

The discrepancy of the imbalance index versus the Bottleneck test is not new; Bos et al. (2008) stated that similar results may be explained by the severity and the age of the bottleneck and/or the stability of the molecular signal (King et al. 2000; Garza \& Williamson 2001). In fact, whereas the $\ln \beta$ metric is known for its ability and power to detect historic signals of expansion (King et al. 2000), the Bottleneck test is suited for the detection of recent reductions in size (that lead to shifts from HWE) but is insensitive to earlier events (Cornuet \& Luikart 1996). In fact, the Bottleneck test is known to be sensitive to gene flow, which rapidly degrades the signal of past bottlenecks (Busch et al. 2007).

\section{Hierarchical analysis of molecular variance}

A substantial lack of genetic structure was found with AMOVA analyses. No spatial structure was found, despite the fact that samples were collected hundreds of kilometers apart along the Western Mediterranean. These results are in perfect agreement with recent studies that utilized mtDNA sequence analyses (Maggio et al. 2009; Roldán et al. 2009; Fernández et al. 2011).

The analysis of the variance of microsatellite data showed that most of the genetic variation was attributable to inter-individual differences $(99.33 \%)$. Similarly, intrasample differences calculated from mtDNA ranged from 96.5\% (Roldán et al. 2009) to 98.3\% (Maggio et al. 2009). Recently, high levels of genetic homogeneity have also been detected among vertical samples of $A$. antennatus from the Catalan Sea (Sardà et al. 2010). All these results are consistent with the biology of the species that uses both larval dispersal strategy and adult migration behavior to disperse individuals and their genetic information widely.

This result is not surprising considering that in shrimps, genetic differentiation is thought to be progressively less appreciable in those species whose life cycles appear to provide greater opportunities for the mixing of populations (Mulley \& Latter 1980).

In fact, following Dall et al.'s (1990) life history classification of Penaeoid shrimps, A. antennatus is characterized by a type 4 life history, typical of species that spend all their life in offshore regions, with potential great opportunities for mixing.

\section{Sex-biased dispersal}

In the present study, samples caught at very different depths were analyzed. It is plausible to hypothesize that individuals that live at different depths are subject to different marine currents and environmental conditions that influence their dispersal capabilities. Furthermore, these populations not only are subject to different conditions but have a different composition in males and females. In fact, in A. antennatus there is a predominance of males under $800 \mathrm{~m}$ depth, whereas females are usually found in shallower waters. This peculiar distribution of individuals with depth leads to the hypothesis that specimens of different sexes can occur in connection with different systems of marine currents (Guijarro et al. 2008).

As seen in Guijarro et al. (2008) the adult females of A. antennatus seem to be in strict association with the warm and saline Levantine Intermediate Waters, whereas adult males are more correlated with the cold Western Mediterranean Deep Waters. On this basis, those authors hypothesized two different mobility patterns for the different sexes in relation to these observed differences. The important role of water masses for A. antennatus, with particular attention to the Deep Water that influences male distribution, was also discussed by Ghidalia \& Bourgois (1961), Bombace (1975), Relini \& Orsi Relini (1987) and Demestre \& Martín (1993).

For marine species that are particularly vagile, estimating dispersal by direct observations is not feasible. Genetic methods can be used to give insights into how dispersal translates into effective dispersal and gene flow. Differences in the dispersal between the sexes can be tested indirectly using microsatellite data. In this case, genetic methods permit detection of only short-term (instantaneous) dispersal, as this signal disappears after the dispersing individuals mate, due to the Mendelian segregation of biparental markers (Goudet et al. 2002).

In the dispersing sex, individuals sampled from a single patch will be a combination of residents and immigrants, hence a heterozygote deficit (a higher $\mathrm{F}_{\mathrm{IS}}$ ) is expected due to the Wahlund effect (Goudet et al. 2002). Furthermore, a relatively higher frequency of rarer genotypes is expected and this is indicated by a negative mAIc value (Paetkau et al. 1995; Prugnolle \& de Meeus 2002) and a larger variance, vAIc (Favre et al. 1997). For the same reason, dispersal leads to lower relatedness $(r)$ and inter-population differentiation $\left(\mathrm{F}_{\mathrm{ST}}\right)$ (Goudet et al. 2002; Prugnolle \& de Meeus 2002). 
In our study, four measurements indicate female-biased dispersal: $\mathrm{F}_{\mathrm{IS}}$ and vAIc values resulted in more $\mathrm{F}$ than $\mathrm{M}$, and $\mathrm{r}$ and $\mathrm{mAIc}$ values were negative in $\mathrm{F}$ while positive in M. Therefore, it can be hypothesized that in A. antennatus, thanks to the Levantine Intermediate Waters, females can disperse more easily, whereas males are tied to the more stable and weak Deep Water Circulation and hence contribute less to the mixing of red and blue shrimp populations.

These mechanisms influencing the genetic flow and structure of the species, are fundamental to understand its biology, leading to an aware management of this precious resource.

Our genetic assessment of red and blue shrimp provides a baseline from which Aristeus antennatus populations can be appraised in the future.

The high level of genetic diversity in this species may help to buffer it from the detrimental genetic effects of increasing fishing pressure.

In theory, large population sizes and high fecundities tend to make A. antennatus scarcely susceptible to population collapse. However, a very high rate of exploitation (higher than the present one) could exacerbate the magnitude of natural population fluctuations and thereby reduce the effective population size over time, with detrimental genetic effects.

Genetic monitoring could help to promptly identify negative effects on genetic diversity caused by fisheries and to plan sound management and conservation measures.

\section{Acknowledgements}

The main results of the present work were presented during the Workshop and included in the final report of the Project REDs founded by the EU (Project ref FISH/2004/03-32).

\section{References}

Anderson J.A., Churchill G.A., Autrique J.E., Tanksley S.D., Sorrells M.E. (1993) Optimizing parental selection for genetic-linkage maps. Genome, 36, 181-186.

Ball A.O., Chapman R.W. (2003) Population genetic analysis of white shrimp, Litopenaeus setiferus, using microsatellite genetic markers. Molecular Ecology, 12, 2319-2330.

Ball A.O., Leonard S., Chapman R.W. (1998) Characterization of (GT)n microsatellites from native white shrimp (Penaeus setiferus). Molecular Ecology, 7, 1251-1253.

Bekkevold D., Hansen M.M., Mensberg K.-L.D. (2004) Genetic detection of sex-specific dispersal in historical and contemporary populations of anadromous brown trout Salmo trutta. Molecular Ecology, 13, 1707-1712.

Berry O., Tocher M.D., Sarre S.D. (2004) Can assignment tests measure dispersal? Molecular Ecology, 13, 551-561.
Bilgin R. (2007) Kgtests: a simple Excel Macro program to detect signatures of population expansion using microsatellites. Molecular Ecology Notes, 7, 416-417.

Bombace G. (1975) Considerazioni sulla distribuzione delle popolazioni di livello batiale con particolare riferimento a quelle bentoniche. Pubblicazioni della Stazione Zoologica di Napoli, 39(Suppl. 1), 7-21.

Borrell Y.J., Arenal F., Mbemba Z.M., Santana O., Díaz-Férnandez R., Vázquez E., Blanco G., Sánchez J.A., Espinosa G. (2007) Spatial and temporal genetic analysis of the Cuban white shrimp Penaeus (Litopenaeus) schmitti. Aquaculture, 272, S125-S138.

Bos D.H., Gopurenko D., Williams R.N., DeWoody J.A. (2008) Inferring population history and demography using microsatellites, mitochondrial DNA, and major histocompatibility complex (MHC) genes. Evolution, 62, 1458-1468.

Botstein D., White R.L., Skolnick M., Davis R.W. (1980)

Construction of a genetic linkage in man using restriction fragment length polymorphism. American Journal of Human Genetics, 32, 314-331.

Brooker A.L., Benzie J.A.H., Blair D., Versini J.J. (2000) Population structure of the giant tiger prawn Penaeus monodon in Australian waters, determined using microsatellite markers. Marine Biology, 136, 149-157.

Busch J.D., Waser P.M., DeWoody J.A. (2007) Recent demographic bottlenecks are not accompanied by a genetic signature in banner-tailed kangaroo rats (Dipodomys spectabilis). Molecular Ecology, 16, 2450-2462.

Cannas R., Buccoli S., Sacco F., Marcias S., Salvadori S., Cau A., Deiana A. (2008) Isolation and characterization of 14 polymorphic microsatellite markers for the blue and red shrimp, Aristeus antennatus (Crustacea, Decapoda). Molecular Ecology Resources, 8, 1420-1422.

Carbonell A., Lloret J., Demestre M. (2008) Relationship between condition and recruitment success of red shrimp (Aristeus antennatus) in the Balearic Sea (Northwestern Mediterranean). Journal of Marine Systems, 71, 403-412. Carbonell A., Dos Santos A., Alemany F., Vélez-Belchi P. (2010) Larvae of the red shrimp Aristeus antennatus (Decapoda: Dendrobranchiata: Aristeidae) in the Balearic Sea: new occurrences fifty years later. Marine Biodiversity Records, 3, e103.

Cartes J.E., Demestre M. (2003) Estimating secondary production in the deep-water shrimp, Aristeus antennatus (Risso, 1816) in the Catalan-Balearic Basin (Western Mediterranean). Journal of Northwest Atlantic Fishery Science, 31, 355-361. Cartes J.E., Sardà F. (1993) Zonation of deep-sea decapod fauna in the Catalan Sea (Western Mediterranean). Marine Ecology Progress Series, 94, 27-34.

Cartes J.E., Papiol V., Guijarro B. (2008) The feeding and diet of the deep-sea shrimp Aristeus antennatus off the Balearic Islands (Western Mediterranean): influence of environmental factors and relationship with the biological cycle. Progress in Oceanography, 79, 37-54.

Cartes J.E., Maynou F., Fanelli E., Papiol V., Lloris D. (2009) Long-term changes in the composition and diversity of 
deep-slope megabenthos and trophic webs off Catalonia (western Mediterranean): are trends related to climatic oscillations? Progress in Oceanography, 82, 32-46.

Carvajal-Rodriguez A., de Una-Alvarez J., Rolan-Alvarez E. (2009) A new multitest correction (SGoF) that increases its statistical power when increasing the number of tests. BMC Bioinformatics, 10, 209.

Chapuis M.-P., Estoup A. (2007) Microsatellite null alleles and estimation of population differentiation. Molecular Biology and Evolution, 24, 621-631.

Company J.B., Puig P., Sardà F., Palanques A., Latasa M., Scharek R. (2008) Climate influence on deep sea populations. PLoS ONE, 3, e1431.

Cornuet J.M., Luikart G. (1996) Description and power analysis of two tests for detecting recent population bottlenecks from allele frequency data. Genetics, 144, 2001-2014.

Cowen R.K., Gawarkiewicz G., Pineda J., Thorrold S.R., Werner F.E. (2007) Population connectivity in marine systems: an overview. Oceanography, 20, 14-21.

Crosnier A., Forest J. (1973) Les crevettes profondes de l'Atlantique oriental tropical. ORSTOM, Paris: 1-409.

Dall W., Hill B.J., Rothlisberg P.C., Sharples D.J. (1990) Advances in Marine Biology: The Biology of the Penaeoidae. Academic Press Limited, London: 489 pp.

Demestre M., Martín P. (1993) Optimum exploitation of a demersal resource in the western Mediterranean: the fishery of the deep-water shrimp Aristeus antennatus (Risso, 1816). Scientia Marina, 57, 175-182.

Dempster A.P., Laird N.M., Rubin D.B. (1977) Maximum likelihood from incomplete data via the EM algorithm. Journal of the Royal Statistical Society. Series B (Methodological), 39, $1-38$.

D’Onghia G., Capezzuto F., Mytilineou C., Maiorano P., Kapiris K., Carlucci R., Sion L., Tursi A. (2005) Comparison of the population structure and dynamics of Aristeus antennatus (Risso, 1816) between exploited and unexploited areas in the Mediterranean Sea. Fisheries Research, 76, 22-38.

D’Onghia G., Maiorano P., Capezzuto F., Carlucci R., Battista D., Giove A., Sion L., Tursi A. (2009) Further evidences of deep-sea recruitment of Aristeus antennatus (Crustacea: Decapoda) and its role in the population renewal on the exploited bottoms of the Mediterranean. Fisheries Research, 95, 236-245.

Dos Santos A. (1998) On the occurrence of larvae of Parapenaeus longirostris (Crustacea: Decapoda: Penaeoidea) off the Portuguese coast. Journal of Natural History, 32, 1519-1523.

Excoffier L., Smouse P.E., Quattro J.M. (1992) Analysis of molecular variance inferred from metric distances among DNA haplotypes: application to human mitochondrial DNA restriction data. Genetics, 131, 479-491.

Excoffier L., Laval G., Schneider S. (2005) Arlequin (version 3.0): an integrated software package for population genetics data analysis. Evolutionary Bioinformatics Online, 1, $47-50$.
Favre L., Balloux F., Goudet J., Perrin N. (1997) Female-biased dispersal in the monogamous mammal Crocidura russula: evidence from field data and microsatellite patterns. Proceedings of the Royal Society of London. Series B: Biological Sciences, 264, 127-132.

Fernández M.V., Heras S., Maltagliati F., Turco A., Roldán M.I. (2011) Genetic structure in the blue and red shrimp Aristeus antennatus and the role played by hydrographical and oceanographical barriers. Marine Ecology Progress Series, 421, 163-171.

Garza J.C., Williamson E.G. (2001) Detection of reduction in population size using data from microsatellite loci. Molecular Ecology, 10, 305-318.

Ghidalia W., Bourgois F. (1961) Influence of temperature and light on the distribution of shrimps in medium and great depths. FAO General Fisheries Council for the Mediterranean Studies and Reviews, 16, 1-49.

Goudet J., Perrin N., Waser P. (2002) Tests for sex-biased dispersal using bi-parentally inherited genetic markers. Molecular Ecology, 11, 1103-1114.

Guijarro B., Massuti E., Moranta J., Diaz P. (2008) Population dynamics of the red shrimp Aristeus antennatus in the Balearic Islands (western Mediterranean): short spatiotemporal differences and influence of environmental factors. Journal of Marine Systems, 71, 385-402.

Hedgecock D., Launey S., Pudovkin A., Naciri Y., Lapègue S., Bonhomme F. (2007) Small effective number of parents $(\mathrm{Nb})$ inferred for a naturally spawned cohort of juvenile European flat oysters Ostrea edulis. Marine Biology, 150, 1173-1182.

Heldt J.H. (1954) Stades larvaires d'Aristeomorpha foliacea (Risso) et Aristeus antennatus (Risso), Décapodes Penéides. Comptes Rendus Académie de Sciences, 239, 1080-1082.

Heldt J.H. (1955) Contribution à l'étude de la biologie des crevettes pénéides Aristaeomorpha foliacea (Risso) et Aristeus antennatus (Risso) (Formes larvaires). Bulletin de la Société des Sciences Naturelles de Tunisie, VIII 1-2, 1-29.

Kapiris K. (2004) Biology and fishery of Aristaeomorpha foliacea (Risso, 1827) and Aristeus antennatus (Risso, 1816) (Decapoda: Dendrobranchiata). Ph.D. thesis, University of Athens, Athens.

Kimmel M., Chakraborty R., King J.P., Bamshad M., Watkins W.S., Jorde L.B. (1998) Signatures of population expansion in microsatellite repeat data. Genetics, 148, 1921-1930.

King J.P., Kimmel M., Chakraborty R. (2000) A power analysis of microsatellite-based statistics for inferring past population growth. Molecular Biology and Evolution, 17, 1859-1868.

Lawson Handley L.J., Perrin N. (2007) Advances in our understanding of mammalian sex-biased dispersal. Molecular Ecology, 16, 1559-1578.

Leberg P.L. (2002) Estimating allelic richness: effects of sample size and bottlenecks. Molecular Ecology, 11, 2445-2449.

Li Y., Wongprasert K., Shekhar M., Ryan J., Dierens L., Meadows J., Preston N., Coman G., Lyons R.E. (2007) Development of two microsatellite multiplex systems for black tiger 
shrimp Penaeus monodon and its application in genetic diversity study for two populations. Aquaculture, 266, 279-288.

Luikart G., Allendorf F., Cornuet J.-M., Sherwin W. (1998) Distortion of allele frequency distributions provides a test for recent population bottlenecks. Journal of Heredity, 89, 238-247.

Maggio T., Lo Brutto S., Cannas R., Deiana A.M., Arculeo M. (2009) Environmental features of deep-sea habitats linked to the genetic population structure of a crustacean species in the Mediterranean Sea. Marine Ecology, 30, 354-365.

Maggioni R., Rogers A.D., Maclean N. (2003) Population structure of Litopenaeus schmitti (Decapoda: Penaeoidae) from the Brazilian coast identified using six polymorphic microsatellite loci. Molecular Ecology, 12, 3213-3217.

Manly B.F.J. (1985) The Statistics of Natural Selection on Animal Populations. Chapman and Hall, London: 484 pp.

Marchi A.L., Cauli G., Greco S., Cau A. (1995) Genetic variation in Aristeus antennatus (Crustacea: Aristeidae) in the Mediterranean basin: analysis of 16 enzyme loci. Biologia Marina Mediterranea, 2, 495-498.

Massuti E., Monserrat S., Oliver P., Moranta J., Lopez-Jurado J.L., Marcos M., Hidalgo M., Guijarro B., Carbonell A., Pereda P. (2008) The influence of oceanographic scenarios on the population dynamics of demersal resources in the western Mediterranean: hypothesis for hake and red shrimp off Balearic Islands. Journal of Marine Systems, 71, 421-438.

Matarrese A., D’Onghia G., De Florio M., Panza M., Costantino G. (1995) Recenti acquisizioni sulla distribuzione batimetrica di Aristaeomorpha foliacea ed Aristeus antennatus (Crustacea Decapoda) nel Mar Ionio. Biologia Marina Mediterranea, 2, 299-300.

Maynou F. (2008a) Environmental causes of the fluctuations of red shrimp (Aristeus antennatus) landings in the Catalan Sea. Journal of Marine Systems, 71, 294-302.

Maynou F. (2008b) Influence of the North Atlantic Oscillation on Mediterranean deep-sea shrimp landings. Climate Research, 36, 253-257.

Meng X.H., Wang Q.Y., Jang I.K., Liu P., Kong J. (2009) Genetic differentiation in seven geographic populations of the fleshy shrimp Penaeus (Fenneropenaeus) chinensis based on microsatellite DNA. Aquaculture, 287, 46-51.

Miller S.A., Dykes D.D., Polesky H.F. (1988) A simple salting out procedure for extracting DNA from human nucleated cells. Nucleic Acids Resources, 16, 1215.

Mulley J.C., Latter B.D.H. (1980) Genetic variation and evolutionary relationships within a group of thirteen species of Penaeoid prawns. Evolution, 34, 904-916.

Mura M., Cau A. (1989) Sul dimorfismo sessuale e sex-ratio in Aristeus antennatus (Risso, 1816). Oebalia, 15, 811-814.

Mura M., Orrù F., Cau A. (1997) Osservazioni sull'accrescimento di individui in fase pre-riproduttiva di Aristeus antennatus e Aristaeomorpha foliacea. Biologia Marina Mediterranea, 4, 254-261.
Nei M. (1987) Molecular Evolutionary Genetics. Columbia University Press, New York: 512 pp.

Nouar A. (2001) Bio-écologie de Aristeus antennatus (Risso, 1816) et de Parapenaeus longirostris (Lucas, 1846) des côtes algériennes. Rapports et procès-verbaux des réunions/ Commission Internationale pour l'Exploration Scientifique de la Mer Méditerranée, 36, 304.

Paetkau D., Calvert W., Stirling I., Strobeck C. (1995) Microsatellite analysis of population structure in Canadian polar bears. Molecular Ecology, 4, 347-354.

Papaconstantinou C., Kapiris K. (2001) Distribution and population structure of the red shrimp (Aristeus antennatus) on an unexploited fishing ground in the Greek Ionian Sea. Aquatic Living Resources, 14, 303-312.

Park S.D.E. (2001) Trypanotolerance in west African cattle and the population genetic effects of selection. Ph.D. thesis, University of Dublin.

Peakall R.O.D., Smouse P.E. (2006) GENALEX 6: genetic analysis in Excel. Population genetic software for teaching and research. Molecular Ecology Notes, 6, 288-295.

Piry S., Luikart G., Cornuet J. (1999) BOTTLENECK: a computer program for detecting recent reductions in the effective population size using allele frequency data. Journal of Heredity, 90, 502-503.

Piry S., Alapetite A., Cornuet J.-M., Paetkau D., Baudouin L., Estoup A. (2004) GENECLASS2: a software for genetic assignment and first-generation migrant detection. Journal of Heredity, 95, 536-539.

Pla C., Roldán M., García-Marín J. (1995) Biochemical genetics of the pink prawn, Aristeus antennatus Risso, in the western Mediterranean. Rapports et procès-verbaux des réunions/Commission Internationale pour l'Exploration Scientifique de la Mer Méditerranée, 34, 39.

Prugnolle F., de Meeus T. (2002) Inferring sex-biased dispersal from population genetic tools: a review. Heredity, 88, 161-165.

Queller D.C., Goodnight K.F. (1989) Estimating relatedness using genetic markers. Evolution, 43, 258-275.

Rannala B., Mountain J.L. (1997) Detecting immigration by using multilocus genotypes. Proceedings of the National Academy of Sciences of the United States of America, 94, 9197-9201.

Reich D.E., Goldstein D.B. (1998) Genetic evidence for a Paleolithic human population expansion in Africa. Proceedings of the National Academy of Sciences of the United States of America, 95, 8119-8123.

Reich D., Feldman M., Goldstein D. (1999) Statistical properties of two tests that use multilocus data sets to detect population expansions. Molecular Biology and Evolution, 16, 453.

Relini Orsi L. (1980) Aspetti risproduttivi in Aristeus antennatus (Risso, 1816) (Decapoda, Penaeide). Memorie di Biologia Marina e Oceanografia, X, 285-289.

Relini G., Orsi Relini L. (1987) The decline of red-shrimps stocks in the gulf of Genoa. Investigacion Pesquera, 51, 245-260.

Relini M., Maiorano P., D’Onghia G., Relini L.O., Tursi A., Panza M. (2000) A pilot experiment of tagging the deep 
shrimp Aristeus antennatus (Risso, 1816). Scientia Marina, 64, 357-361.

Robainas-Barcia A., Lopez G.E., Hernandez D., Garcia-Machado E. (2005) Temporal variation of the population structure and genetic diversity of Farfantepenaeus notialis assessed by allozyme loci. Molecular Ecology, 14, 2933-2942.

Robainas-Barcia A., Blanco G., Sánchez J., Monnerot M., Solignac M., García-Machado E. (2008) Spatio-temporal genetic differentiation of Cuban natural populations of the pink shrimp Farfantepenaeus notialis. Genetica, 133, 283-294.

Roldán M.I., Heras S., Patellani R., Maltagliati F. (2009) Analysis of genetic structure of the red shrimp Aristeus antennatus from the Western Mediterranean employing two mitochondrial regions. Genetica, 136, 1-4.

Rousset F. (2008) genepop'007: a complete re-implementation of the genepop software for Windows and Linux. Molecular Ecology Resources, 8, 103-106.

Sardà F., Cartes J.E., Norbis W. (1994) Spatio-temporal structure of the deep-water shrimp Aristeus antennatus (Decapoda: Aristeidae) population in the Western Mediterranean. Fishery Bulletin, 92, 599-607.

Sardà F., Bas C., Roldán M.I., Pla C., Lleonart J. (1998) Enzymatic and morphometric analyses in Mediterranean populations of the rose shrimp, Aristeus antennatus (Risso, 1816). Journal of Experimental Marine Biology and Ecology, 221, 131-144.

Sardà F., Company J.B., Castellon A. (2003a) Intraspecific aggregation structure of a shoal of a Western Mediterranean (Catalan coast) deep-sea shrimp, Aristeus antennatus (Risso, 1816), during the reproductive period. Journal of Shellfish Research, 22, 569-579.

Sardà F., Company J.B., Maynou F. (2003b) Deep-sea shrimp Aristeus antennatus (Risso, 1816) in the Catalan sea, a review and perspectives. Journal of Northwest Atlantic Fishery Science, 31, 127-136.

Sardà F., D’Onghia G., Politou C.Y., Company J.B., Maiorano P., Kapiris K. (2004) Deep-sea distribution, biological and ecological aspects of Aristeus antennatus (Risso, 1816) in the western and central Mediterranean Sea. Scientia Marina, 68, 117-127.

Sardà F., Roldán M.I., Heras S., Maltagliati F. (2010) Influence of the genetic structure of the red and blue shrimp, Aristeus antennatus (Risso, 1816), on the sustainability of a deep-sea population along a depth gradient in the western Mediterranean. Scientia Marina, 74, 569-575.
Seridji A. (1971) Contribution a l'étude des larves crustacés décapodes en baie d'Alger. Pelagos, 3, 1-107.

Supungul P., Sootanan P., Klinbunga S., Kamonrat W., Jarayabhand P., Tassanakajon A. (2000) Microsatellite polymorphism and the population structure of the black tiger shrimp (Penaeus monodon) in Thailand. Marine Biotechnology, 2, 339-347.

Tassanakajon A., Tiptawonnukul A., Supungul P., Rimphanitchayakit V., Cook D., Jarayabhand P., Klinbunga S., Boonsaeng V. (1998) Isolation and characterization of microsatellite markers in the black tiger prawn Penaeus monodon. Molecular Marine Biology and Biotechnology, 7, 55-61.

Ward R., Ovenden J., Meadows J., Grewe P., Lehnert S. (2006) Population genetic structure of the brown tiger prawn, Penaeus esculentus, in tropical northern Australia. Marine Biology, 148, 599-607.

Weir B.S. (1996) Genetic Data Analysis II: Methods for Discrete Population Genetic Data. Sinauer Assoc. Inc., Sunderland, MA: 376 pp.

Weir B.S., Cockerham C.C. (1984) Estimating F-statistics for the analysis of population structure. Evolution, 38, 13581370.

Wright J.M., Bentzen P. (1994) Microsatellites - genetic-markers for the future. Reviews in Fish Biology and Fisheries, 4, 384-388.

Xu Z., Dhar A.K., Wyrzykowski J., Alcivar-Warren A. (1999) Identification of abundant and informative microsatellites from shrimp (Penaeus monodon) genome. Animal Genetics, 30, 150-156.

Xu Z.K., Primavera J.H., de la Pena L.D., Pettit P., Belak J., Alcivar-Warren A. (2001) Genetic diversity of wild and cultured Black Tiger Shrimp (Penaeus monodon) in the Philippines using microsatellites. Aquaculture, 199, 13-40.

Yeh F., Rong-Cai Y., Boyle T. (1998) POPGENE, Version 1.31 Microsoft Window-Based Freeware for Population Genetic Analysis: Quick User Guide. University of Alberta, Center for International Forestry Research, Edmonton, $\mathrm{AB}$, Canada: $28 \mathrm{pp}$.

You E.M., Chiu T.S., Liu K.F., Tassanakajon A., Klinbunga S., Triwitayakorn K., de la Pena L.D., Li Y., Yu H.T. (2008) Microsatellite and mitochondrial haplotype diversity reveals population differentiation in the tiger shrimp (Penaeus monodon) in the Indo-Pacific region. Animal Genetics, 39, 267-277. 